\title{
Small Polities: Tyrannized by Majorities?
}

\author{
Dag Anckar*
}

Professor Emeritus of Political Science, Åbo Akademi University, Department of Political Science, Biskopsgatan 15, 20500 Åbo 50, Finland

\begin{abstract}
Several studies have established that small states are more likely than large states to be democratic. However, the belief that smallness is a virtue when and if a democratic form of government is desired has not gone unchallenged. Already in The Federalist Paper, the view was given that small democracies can admit of no cure for the mischiefs of faction and are therefore especially vulnerable to the risk of the tyranny of the majority. The core of this argument, then, is that smallness, even if democratic, is likely to be dominated by the few. Investigating while noting that dominance may mean different things in varying institutional settings patterns of dominance since the early 1970s in the microstates of the world, this essay attempts to bring in a verdict in this controversy. The findings are that small polities are indeed not as a rule tyrannized by majorities. Within the small polity universe, there is much variation in terms of dominance, and in this framework of variation, non-dominance clearly outweighs dominance: of 73 time periods during which state performances are observed, 42 are in a category of non-dominance. Much of this variation may be explained by democracy variation. Democratic countries display non-dominance in the great majority of cases; in contrast, nondemocracy links predominantly to dominance.
\end{abstract}

\section{INTRODUCTION}

Robert Dahl and Edward Tufte start their by now classical treatise on Size and Democracy by noting that until the end of the eighteenth century there was little dissent among political philosophers from the view that a democracy had to be small (Dahl \& Tufte, 1973: 4). Dahl and Tufte also note that the idea that democracy is somehow linked with smallness has retained considerable appeal, as opponents of centralization, supporters of local government, advocates of grass-root or participatory democracy and the like all have continued to defend the special virtues of democracy in smaller territorial units (Dahl \& Tufte, 1973: 12-13). And to be sure, many recent studies on small state politics have established that small size reinforces popular rule and that small states are more likely than large states to be democratic (e.g. Diamond \& Tsalik, 1999; Ott, 2000; D. Anckar, 2002). Summarizing several of these studies Henry Srebrnik has therefore concluded that statistical as well as anecdotic evidence indicates that small country size is indeed conducive to democracy (Srebrnik, 2004: 339).

However, the belief that smallness is a virtue when and if a democratic form of government is desired has not gone unchallenged. It has been contradicted by the view, presented already in The Federalist Paper by James Madison (Hamilton et al., 1961: 82-84), that small size is really a curse whereas larger size is, instead, a blessing. Dahl and Tufte, in their overview of claims and counter-claims in regards to size, make full justice to this challenge. According to Dahl and Tufte, Madison 'met the classical position head on and triumphantly turned it around', contending that far

*Address correspondence to this author at the Professor Emeritus of Political Science, Åbo Akademi University, Department of Political Science, Biskopsgatan 15, 20500 Åbo 50, Finland; Tel: (358)-2-2154316; Fax: (358)-2-2154585; E-mail: dag.anckar@abo.fi from being a disadvantage, size was actually an advantage (Dahl \& Tufte, 1973:10). Any democracy, Madison insisted, had to face the danger that a passionate majority might 'sacrifice to its ruling passion or interest both the public good and the rights of other citizens' (quotation from Dahl \& Tufte, 1973: 10). Since, in the view of Madison, a small direct democracy along classical lines can admit of no cure for the mischiefs of faction, it follows that small units are especially vulnerable to the risk of the tyranny of the majority. As against this, a representative republic opens a different prospect, and promises a cure. Namely, the greater the size, the greater the variety of parties and interests, and hence the less the probability 'that a majority of the whole will have a common motive to invade the rights of other citizens; or if such a common motive exists, it will be more difficult for all who feel it to discover their own strength, and to act in unison with each other' (quotation from Dahl \& Tufte, 1973: 11). In other words: large units tend towards heterogeneity and incorporate a wide variety of interests as well as generate different coalitions. This being so, no identifiable group of people has any manifest motive for calling the legitimacy of the democratic system in question (Hamilton et al., 1961: 84; C. Anckar, 2008: 434).

This controversy over size was, properly speaking, about the practices and prospects of direct and representative government on a national scale. This paper takes a slightly different view of the controversy as it focuses on the claim that small units are vulnerable to the risk of the tyranny of the majority. In other words, the classical controversy is reframed to concern the belief that whereas small size promotes a petrification of present power figurations, larger size promotes, instead, a disintegration and decomposition of the corresponding figurations. The not so small polities, to quote a hypothesis formulation by Dahl and Tufte (1973: 14), reduce the likelihood that a single interest of one segment of the members will dominate the whole system; in 
contrast, the small polity provides less opportunity for divergence of views on individual, group, and general interests and goals. From this follows that the small polity is terrorized by the majority in so far as this majority, because of the smallness of the context, tends to reproduce itself and to recur over and over again. It is the ambition of the present investigation to submit this characterization to empirical testing, and the research question to be addressed and answered here, then, is the following: is it really the case that small polities are terrorized by majorities, this meaning that they reflect consistent patterns of factional dominance?

The note should be inserted here that the fact that small units tend towards democracy does not imply an automatic disclaimer of the Madison argument. The core of the argument, the validity of which is to be investigated here, is that smallness, even if democratic, is probably dominated by the few. Leading parties have competitors, but only insignificant ones; democracy does not spell an absence of dominace. In the words of Giovanni Sartori: as long as they continue to win an absolute majority electorally, it is consistent with democratic rule for predominant parties to govern alone, without being subjected to alteration (Sartori, 1976: 127). In like manner, Axel Hadenius emphasizes that democracy can surely exist within the frame of a high degree of political consensus, as long as this consensus does not spring from prohibitions, coercion and reprisals (Hadenius, 1992: 37). Indeed, a dominant party system may even emerge as one of several models of democratic stability (Asher \& Barnes, 1972). There is nothing, then, that speaks against the thought that democratic countries may sometimes display dominance; on the other hand, it is equally true that non-democratic countries may sometimes display nondominance. One example, visible also in the materials at hand here is Suriname, short on democracy but also a politically divided nation ridden by ethnic antagonisms (Hoefter \& Oostindie, 1991: 84-86). The extent to which democracy links to dominance and non-democracy to nondominance is an empirical question, and not a matter of logic and inference.

The article has in all five sections. Following this introduction, a second section identifies a set of small states and their democracy status, and also specifies for each state the time period or periods for which the state performance is measured. A third section explains the method for deciding whether or not dominance patterns prevail during the periods of observation, and a fourth section presents and comments upon the ensuing empirical pattern. Finally, the fifth section summarizes the findings and provides concluding remarks.

\section{MICROSTATES AND PERIODS}

This research being about politics in small states, an operationalization of smallness is needed as a point of departure. The operationalization that comes to use here applies microstate conceptions, this meaning that the research is about states with populations of less than one million. Although contested at times (e.g. Ogashiwa, 1991: ix-x), this threshold is the usual one in political science research for distinguishing microstates from other and larger states. More precisely: the present research is about the microstate population of the world in the year 2006, comprising a total of 42 states. However, the effort leaves out Montenegro, which is a newcomer in 2006 to the microstate camp, and which is because of her still very short life span as an independent nation a less relevant case for the empirical study of dominance. The actual research is therefore about 41 microstates, the research question being to what extent these states portrait such dominance patterns in terms of political power that justify a notion of a tyranny of the majority. The states are enumerated in Table $\mathbf{1 .}$

Two considerations guide the establishment of research periods. On the one hand, dominance obviously being a function of time, the very conception of dominance presupposes a certain time span during which dominance can evolve and take shape. In other words, the periods that are to be observed must be long enough to allow dominance to manifest itself. On the other hand, since dominance is not ever-lasting, such periods cannot very well be expected to extend over very long sheets of time. To simplify: if periods are very short, dominance will always prevail; if periods are very long, dominance will never come forth. To balance here these requirements, two operational codes for identifying dominance are used. First, to satisfy the requirement that the period of observation must extend over a not too short period of time, for microstates independent at 1980 or later, the independence sequence up to 2006 is regarded as one period, during which majority rule may have appeared or not. In other words, these states are classified in terms of dominance only once, and they are thus regarded as being once and for all dominance cases or not. Out of 41 microstates, a minority of nine are in this category, the former U.S. territories of Marshall Islands (independent in 1991), Micronesia (1991) and Belau (1994) representing the shortest independence curves, and Vanuatu (independent in 1980), AntiguaBarbuda (1981) and Belize (1981) representing in this category the longest curves.

For the vast majority of cases, another operational strategy is used which accommodates the need to introduce time sequences that are neither too long nor too short. This strategy is to divide the time span from independence to 2006, which year marks for technical reasons the end line of the investigation, into two equally long halves, both of which, then, become units of analysis. For instance, Cape Verde became in 1975 independent from Portuguese rule, and the time span between 1975 and 2006 being 31 years, the division of this span into two halfs makes use of a cutting point of 15,5 years. The implication of this is in operational terms that the dominance constellation in Cape Verde is evaluated separately for the period of $1975-1990$ (=15 years) and the period of 1991-2006 (=16 years). However, for countries independent prior to 1972, the time span runs from 1972, and this operational rule takes care of the awkward fact that some countries are so old in terms of state formation that this renders impossible the use of independence dates. For instance, the years of state formation are 1342 for Liechtenstein, 1297 for Monaco, and, indeed, AD 301 for San Marino (Derbyshire \& Derbyshire, 1999). For such countries, and Cyprus (independence in 1960), Equatorial Guinea (1968) and Guyana (1966) may be given as further examples, the period of investigation runs from 1972 to the present (2006), and the dominance situations are, accordingly, observed and evaluated for two periods, one of which runs from 1972 to 1989 (18 years), whereas the other runs from 1990 to 2006 (17 years). The various 
Table 1. The Microstates of the World (2006). Year of Independence and Democracy Status during Sub-Periods

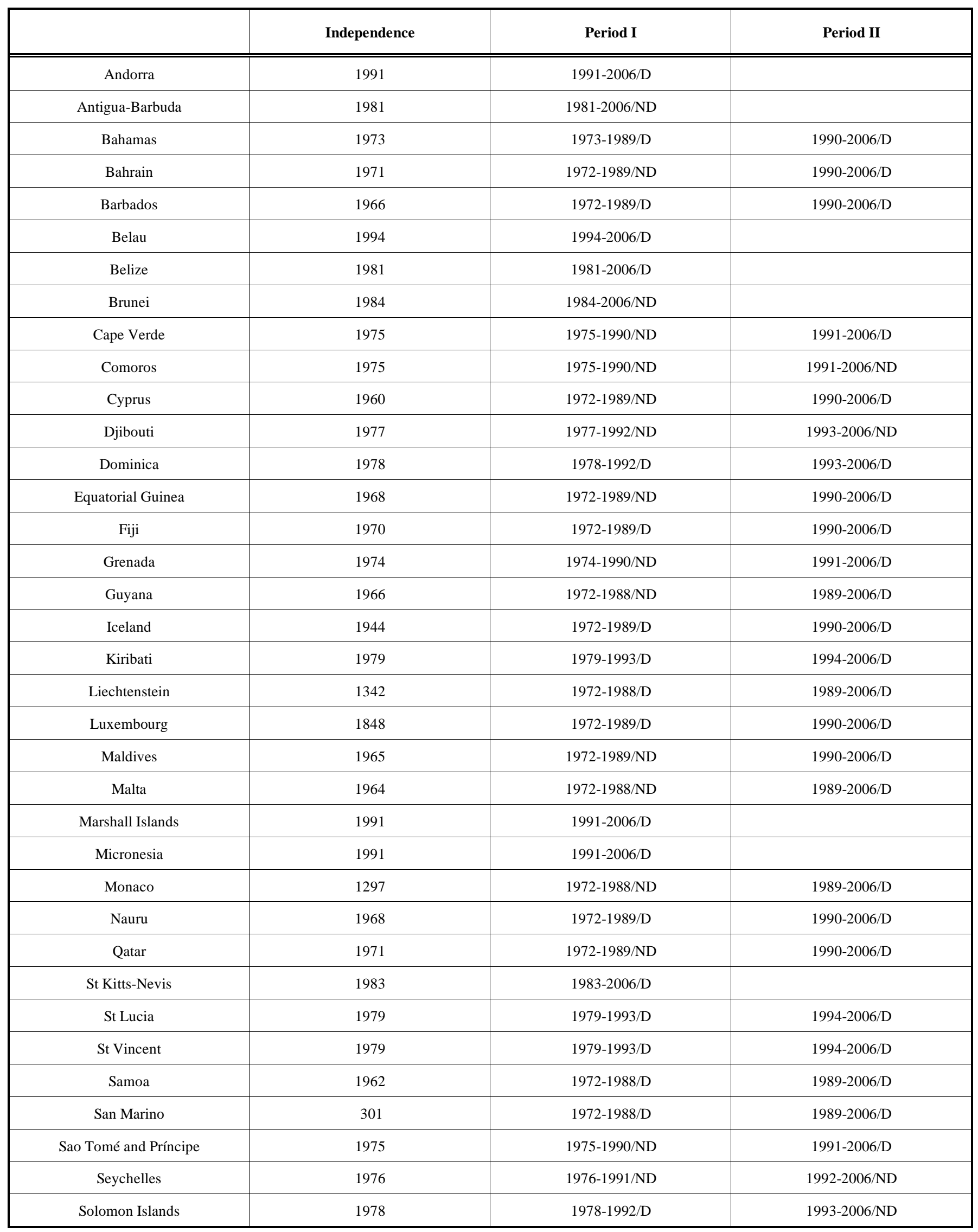


Table 1. Contd....

\begin{tabular}{|c|c|c|c|}
\hline & Independence & Period I & Period II \\
\hline \hline Suriname & 1975 & $1975-1990 / \mathrm{ND}$ & $1991-2006 / \mathrm{ND}$ \\
\hline Tonga & 1875 & $1972-1989 / \mathrm{ND}$ & $1990-2006 / \mathrm{D}$ \\
\hline Tuvalu & 1978 & $1978-1992 / \mathrm{D}$ & $1993-2006 / \mathrm{D}$ \\
\hline Vanuatu & 1980 & $1980-2006 / \mathrm{ND}$ & $1970-1988 / \mathrm{ND}$ \\
\hline Vatican City & 1929 & $1989-2006 / \mathrm{ND}$ \\
\hline
\end{tabular}

Key: $\mathrm{D}$ = democracy period; $\mathrm{ND}=$ non-democracy period.

considerations are summarized in Table 1, which provides for each microstate in the research population information about the respective year of independence and the length of the periods for which dominance patterns are seeked. In all, 73 time periods are identified.

The period of investigation starts from the year 1972 for a reason. Namely, from this year on the Freedom House ratings of the countries in the world are available, and these ratings are used here to introduce a distinction between democratic and non-democratic contexts for domination to appear or disappear. Based on surveys provided by regional experts, consultants and human rights specialists as well as fact-finding missions and public sources, Freedom House monitors since 1972 the progress and decline of political rights and civil liberties in all the nations of the world and in related territories. In essence, the units are rated on sevencategory scales for political rights and civil liberties, and then, on the basis of these ratings, placed into one of the categories of 'Free', 'Partly Free' and 'Not Free'. On each scale, the value 1 represents the most free and value 7 the least free, and the placing of units in categories is dependent on the combined ratings. Generally, countries whose ratings average 1-2.5 are considered 'Free', whereas countries whose ratings average 3-5.5 are considered 'Partly Free' and countries whose ratings average 5.5-7 are considered 'Not Free'. Although it is true that the Freedom House data do not in full discriminate between degrees of freedom and nonfreedom (Foweraker \& Krznaric, 2000: 767), the data are still widely used by social and political scientists and are generally credited with validity as well as reliability. Indeed, by integrating observations on political rights as well as civil liberties, the Freedom House conception of freedom becomes a very good approximation of what should be meant by 'democracy' (D. Anckar, 2007), and this study certainly concurs in the much-quoted view by Larry Diamond that the 'free' rating in the Freedom House survey is the best available empirical indicator of 'liberal democracy' (Diamond, 1996: 24). The analytical point of departure is therefore that at any given point of time, the states may be referred to one of the two categories of democracy and non-democracy, the guiding criterion being the Freedom House rating of the country in question at the actual point of time. Countries rated by Freedom House as 'Free' are classified here to be democratic, whereras countries rated as 'Partly Free' or 'Not Free' are classified as representing non-democratic regimes.

Given that countries may be given differing ratings for individual years during a period, the country ratings must be combined in a meaningful manner. For instance, Cyprus was classified by Freedom House as a democracy for 11 out of 18 years during the first period, and for all 17 years during the second period. While, then, Cyprus was evidently a democracy during the second period, what about the first period? Are 11 confirmative classifications out of 18 enough? Obviously, what is needed is an operational cutting point, and to secure validity, this point should be selected in a way which demands more than a majority of classifications only. Here and now, the operational rule is one that requires $3 / 4$ of the classifications during a designated period to be in the democracy category. If this condition is satisfied, we are talking about a democracy context; if not, the context represents non-democracy. In the case of Cyprus, then, the threshold is not reached, and Cyprus is, in consequence, classified as a non-democracy during the first period.

\section{MEASURING DOMINANCE}

Observations on dominance must of course recognize that forms of dominance are context-dependent. In other words, given variations in institutional settings, dominance may mean different things. Within the frame of reference that is valid here, two main considerations apply. First, dominance obviously takes on different shapes in different regimes. Parliamentary systems offer a different frame for dominance to evolve and live on than do presidential systems and the in-between systems that are usually named semi-presidential (e.g. Elgie, 2008). And of course, implying dominance almost by definition, a variety of regimes are hostile to party politics, allow the existence of one party only, or are characterized by military leaders imposing a government on the people. Such regimes represent authoritarian nationalism, military authoritarianism, islamic nationalism, absolutism, or the like (Derbyshire \& Derbyshire, 1999: 36-43; Karvonen, 2008: 82-86), and are here henceforth referred to as being 'absolute'.

Second, a distinction needs to be introduced in the classificatory scheme between cases that have or do not have political parties. The thought is of course near at hand that this distinction coincides to some extent with the democracyauthoritarianism distinction that was introduced earlier; however, such a conception is false. Most likely, most observers would agree on there being authoritarian regimes with and without parties, and most likely, most observers would agree that democratic regimes, in contrast, function solely through the operation of parties and that "parties are the core institution of democratic politics' (Lipset, 1996: 169). However, whereas the first observation is correct, the 
second is not. There are indeed democracies without parties, and furthermore, these cases are to be found precisely within the microstate camp (Anckar \& Anckar, 2000). This being the case, it becomes necessary to introduce a distinction between democracies with and without parties into the considerations. This distinction has in its wake consequences for the measurement of dominance. Patterns of party competition and party strength are obvious and important footholds in the observation of dominance; when these footholds are not at hand, other measures need to be found and used.

While conveying a point of departure, (Table 2) reports the distribution of the 73 time periods over the regime and party dimensions. Most microstate systems reflecting their colonial masters (D. Anckar, 2004: 208-212) and a good portion of the microstates being small island states with a British colonial past, it comes as no great surprise that the parliamentary regime form is most frequent, more than half of the periods $(53 \%)$ having this institutional framing. The presidential and the absolute regime norms are equally well represented, both framing about one fifth of the periods, while the semipresidential regime form prevails in a few cases only. Concerning the party dimension, close to $3 / 4$ of the periods are by regimes that involve political parties, and most of the periods without parties relate to parliamentary and absolute regimes. Since all eight cells in Table $\mathbf{2}$ are represented by empirical cases, it becomes necessary for the measurement of domination to develop eight formulas for determining whether or not dominance is at hand. Summarized also in Table 3, these formulas are presented here, and empirical examples are inserted to illustrate their use.

Table 2. The Microstate Universe: Distribution of 73 Time Periods Over Regime and Party Dimensions

\begin{tabular}{|c|c|c|}
\hline Regime Form: & Parties: Yes & Parties: No \\
\hline \hline Parliamentary & 31 & 8 \\
\hline Presidential & 10 & 4 \\
\hline Semi-presidential & 4 & 1 \\
\hline Absolute & 8 & 7 \\
\hline Total & 53 & 20 \\
\hline
\end{tabular}

For parliamentary systems that build upon political parties, the general idea of dominance, as stated by Sartori, is clear enough: 'Whenever we find, in a polity, a party that outdistances all the others, this party is dominant in that it is significantly stronger than the others' (Sartori, 1976: 193). The words 'significantly stronger' are here operationalized to imply that the leading party is in control of at least $3 / 4$ of the cabinet seats, and that this dominance is in force during at least $4 / 5$ of the time period in question. Admittedly, these rules, like other rules to be introduced shortly, are somewhat arbitrary and are not altogether strict in so far as they allow for majorities to be undone to some extent. More rigid applications, however, would violate validity claims and would most likely hide rather than uncover patterns of dominance. Anyhow, in regards to parliamentary systems the dominance principle is one of 'most of the seats most of the time', and Bahamas, governed during the first period 19731989 by the Progressive Liberal Party is a dominance case in point. On the other hand, if the above criterion is not met, executive authority being shared between parties, the case at hand is one of non-dominance. Again, Bahamas, governed during the second period 1990-2006 alternate by the Progressive Liberal Party (1990-1992, 2002-2006) and the Free National Movement (1992-2002), is a case in point.

However, if parliamentary regimes are in lack of parties, the operational code must become one that focuses on the individual PM. The rule to be applied here prescribes for a country to exhibit dominance that the same PM has been in power during at least $3 / 4$ of the period in question. This rule, in fact, does not apply to any of the few parliamentary regimes without parties, all cases at hand going into the nondominance category. Tuvalu, for instance, was during the period of 1978-1992 governed by cabinets chaired by Toaripi Lauti, Tomasi Puapua and Bikenibeu Paeniu (Somoza, $2001 \mathrm{c:}$ 831), and thus exhibited a diversity pattern that qualifies for a notion of non-dominance.

In presidential regimes the dominance mechanism is much different. Such regimes have one-person executives, as ministers are merely advisers and sub-ordinates of the president (Lijphart, 1992: 3). Therefore, analytical efforts at establishing executive dominance must depart from the individual President. However, political parties may still become components of this establishment of dominance. When and if the president faces in his assumption of power a parliament which is dominated by other parties than his own, the outcome from this clash may be detrimental to political efficiency and legitimacy (Linz, 1994: 6-8); indeed, 'a conflict is always latent and sometimes likely to erupt dramatically' (Linz, 1994: 7). The political composition of the parliament must therefore be an element of the considerations, and the operational rule is here that dominance is at hand in presidential regimes when the president rules during at least $4 / 5$ of the period in question in collaboration with a parliament in which his party commands a majority. One example is Djibouti, where following independence from France in 1977, President Hassan Gouled Aptidon controlled a one-party system until 1992 (Durotoye, 1999: 301). If the above condition is not satisfied, the period in question is classified as one of non-dominance. Again, in presidential regimes without parties, calculations of dominance must be based on the individual President. The Federated States of Micronesia had four Presidents (Bailey Olter, Jacob Nena, Leo Falcam and Joseph Urusemal) during the years 1991-2006 (Somoza, 2001 a: 641), and is, in consequence, in the materials at hand a typical nondominance case.

In semipresidential systems the executive authority is shared between a directly or semi-directly elected president and a cabinet, which must enjoy parliamentary confidence (e.g. Sartori, 1994: 131-132). Such arrangements, then, are parliamentary and presidential alike, and the dominance criterion must therefore combine elements from the criteria that are applied to parliamentary and presidential regimes proper. In semipresidential systems with parties, the dominance requirement is here that the same president rules and that his party commands a majority of the cabinet seats 
Table 3. List of Criteria for Establishing Dominance in Individual Countries During Individual Periods

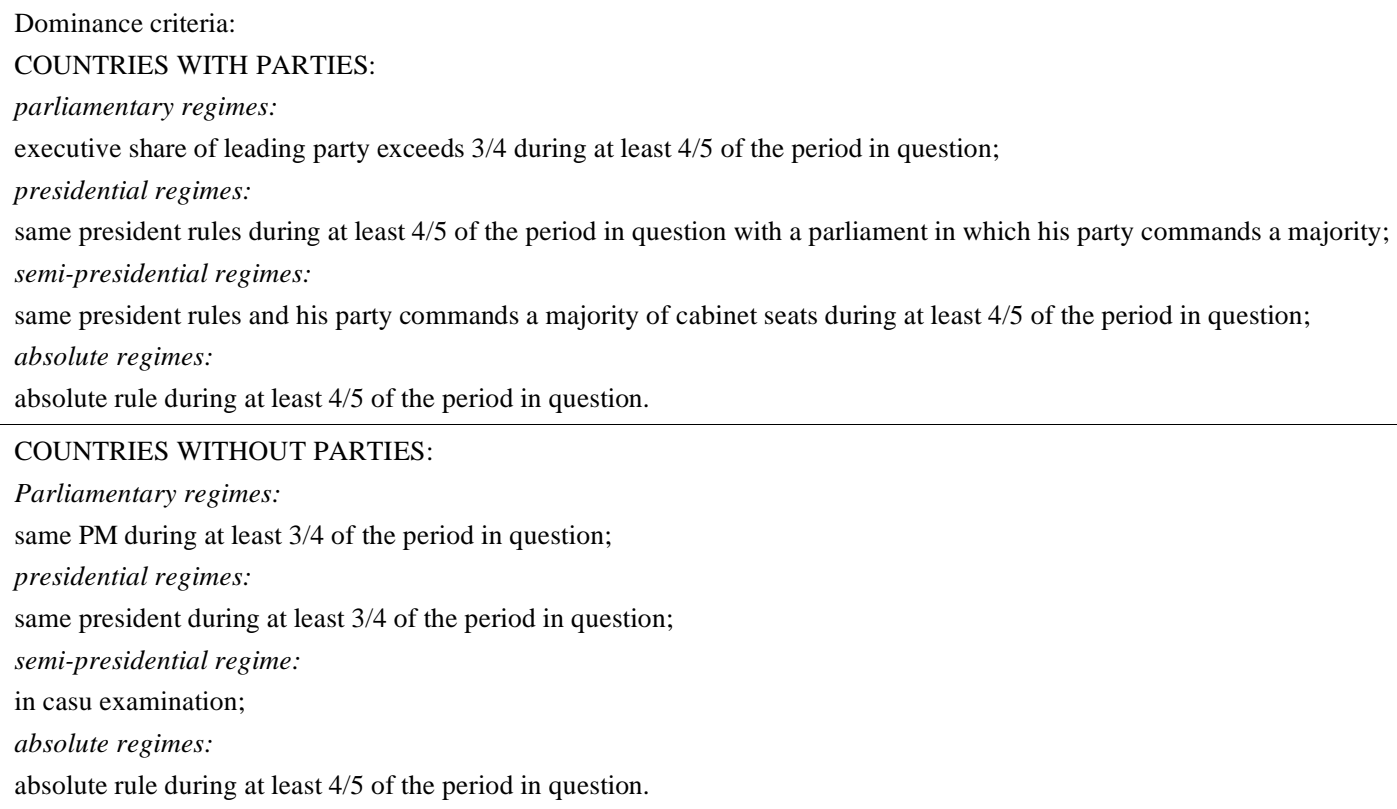

during at least $4 / 5$ of the period in question; if this requirement is not met, the case at hand is one of nondominance. One example of non-dominance is Sao Tomé and Príncipe during the years 1991-2006, the presidency holders being Miguel Trovoada (1991-2001) and Fredique de Menezes (2001-2006), both acting with cabinets drawn from parliaments in which the president party did not command a majority (Fleischhacker, 1999). In systems with no parties, the establishment of a valid measurement device becomes tricky; however, in the present research there is only one case in this category, and this case is easy to decide. Kiribati is during the years 1979-1993 a dominance case, Ieremia Tabai acting as President during the years 19791991 (van Trease, 1993; Somoza, 2001 b: 683).

Concerning absolute regimes, the rule that is applied here is simple and straightforward: whenever such regimes have prevailed in a country during at least $4 / 5$ of the period in question, one confronts dominance. One case in point is the Arab microstate Qatar, ruled since independence in 1971 by absolute monarch Khalifa bin Hamad al-Thami until 1995. A new constitution from the year 2003 has not eliminated the monopoly of power enjoyed by the al-Thami family. Another case in point is the Pacific island state of Tonga, where at the end of the period under observation King Taufa' ahau Tupou IV had reigned since 1945. It needs to be emphasized that the classifications do not change when and if the absolute ruler is replaced by another absolute ruler. Equatorial Guinea may serve as one example. The fact that President Macías was executed in 1979 in a military coup staged by Teodoro Obing, who has ruled the country since then, does not imply, Macías as well as Obing being repressive and tyrannic leaders, any such discontinuity that would introduce and justify a notion of non-dominance.

Of course, individual countries may display very different patterns in the oscillations between dominance and non-dominance. Concerning developments from dominance to non-dominance, Cape Verde is a case in point. Upon independence in 1975, this country was governed for 16 years, i.e. during the whole of the first period, under Marxist one-party rule by the African Party for the Independence of Guinea and Cape Verde (PAICV). This period, then, undoubtedly was one of dominance. Following a democratic breakthrough in 1991, a party called the Movement for Democracy won a landslide victory, and was returned to power in 1995. However, in 2001 the mandate of Antoio Mascarenhas Monteiro ended after he had served two terms as president, and in legislative polls that year, PAICV again captured a majority. The second period therefore displaying signs of competition and power oscillation and the dominance of PAICV not extending over $3 / 4$ of this period, the period cannot be classified as one of dominance. Other cases may uphold dominance in the face of regime change. Seychelles, independent in 1976, is illustrative of such cases. Already in 1977 Albert Rene seized power and ruled for the period of 1977-1992. Following a democratisation of political life in Seychelles during the early 1990s and the introduction in 1993 of a new Constitution (Thibaut, 1999: 775-778), Rene won in 1993 a legitimate electoral mandate and finally resigned as President in 2004. In other words, Seychelles has during almost the whole period been ruled by one man and one party, although the frames for dominance have been different.

\section{EMPIRICAL FINDINGS}

The basic findings of this investigation are summarized in Table 4, which reports, for each and every microstate, whether or not this state has satisfied the dominance criterion under the period or periods in question. The number of cases being fairly small, interpretations are guided by straightforward quantitative observations rather than advanced statistics. As explained earlier, the performances of 32 states have been observed during two periods, whereas nine states are observed during one period only. The total number of periods is therefore 73 , and as evident from the expositions in Table 4, the dominance criterion is satisfied in 31 of these 
Table 4. Microstates During Sub-Periods: Dominance or Not?

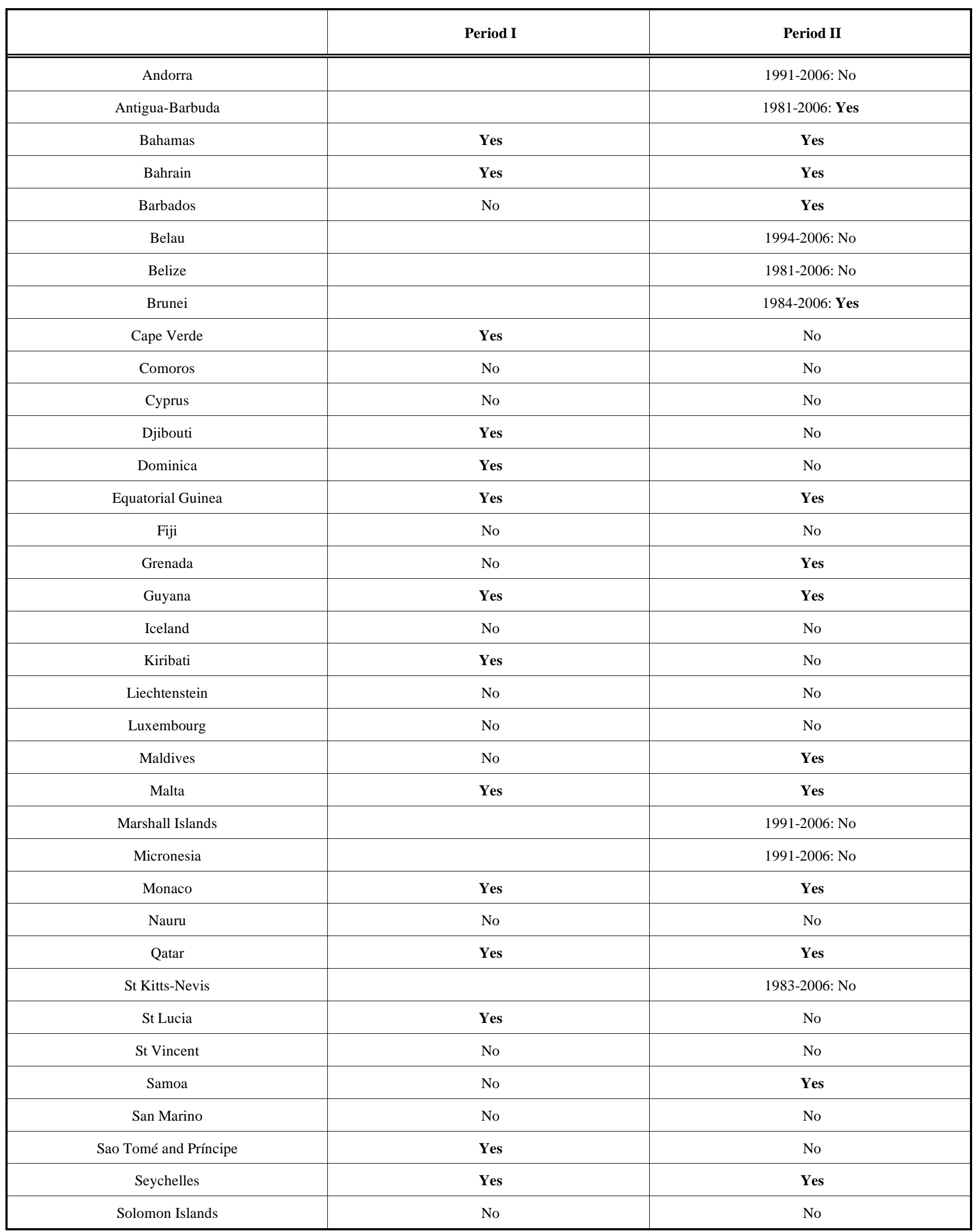


Table 4. Contd....

\begin{tabular}{|c|c|c|}
\hline & Period I & Period II \\
\hline \hline Suriname & No & Yo \\
\hline Tonga & Yes & No \\
\hline Tuvalu & No & 1980-2006: No \\
\hline Vanuatu & & Yes \\
\hline Vatican City & Yes & Nes \\
\hline
\end{tabular}

cases, this number equalling a share of 42 per cent. In other words, dominance appears in clearly less than half but clearly more than two fifths of the cases. There is also in the materials a tendency for dominance to become less visible over time. When the country scores for the first period are compared to the corresponding scores for the second period, the nine countries that are evaluated during one period only being for obvious reasons incorporated into the calculations for the second period, the result is that 50 per cent of the first period units were dominance units as against 37 per cent of the second period units.

This general pattern is delineated further and explained in the configurations that are given in Tables 5-8. First, countries may, dependent on findings, be placed on a continuum which runs from non-dominance always, via a blend of dominance and non-dominance, to dominance always. Describing this subpattern, Table 5 orders the microstates into three categories. The category of nondominance lists countries that have contributed periods of non-dominance only to this research, the category of halfdominance lists countries that have contributed periods of dominance as well as periods of non-dominance, and the category of dominance lists countries that have contributed periods of dominance only. Clearly, the overall pattern is variegated. Close to half of the microstates have not experienced dominance at all; a full quarter of the microstates have experienced nothing but dominance. The in-between category of states that have experienced dominance as well as non-dominance matches exactly the

Table 5. Microstates and Dominance: Distribution of 41 Cases on Three Categories

\begin{tabular}{|c|c|c|}
\hline Andorra & Bahamas & Antigua-Barbuda \\
\hline Belize & Cape Verde & Brunei \\
\hline Comoros & Djibouti & Equatorial Guinea \\
\hline Fiji & Grenada & Malta \\
\hline Iceland & Kiribati & Monaco \\
\hline Liechtenstein & Maldives & Qatar \\
\hline Luxembourg & St Lucia & Seychelles \\
\hline \multicolumn{3}{|l|}{ Nauru } \\
\hline \multicolumn{3}{|l|}{ St Kitts-Nevis } \\
\hline \multicolumn{3}{|l|}{ St Vincent } \\
\hline \multicolumn{3}{|l|}{ San Marino } \\
\hline \multicolumn{3}{|l|}{ Solomon Islands } \\
\hline \multicolumn{3}{|l|}{ Suriname } \\
\hline \multicolumn{3}{|l|}{ Tuvalu } \\
\hline \multicolumn{3}{|l|}{ Vanuatu } \\
\hline
\end{tabular}


Table 6. Democracy and Dominance in the Microstate Camp: Co-Variations Over 41 Cases

\begin{tabular}{|c|c|c|c|}
\hline & $\begin{array}{c}\text { Non-Dominance } \\
\text { Countries }\end{array}$ & $\begin{array}{c}\text { Half-Dominance } \\
\text { Countries }\end{array}$ & $\begin{array}{c}\text { Dominance } \\
\text { Countries }\end{array}$ \\
\hline $\begin{array}{c}\text { Democratic } \\
\text { countries }\end{array}$ & 13 & 6 & 0 \\
\hline $\begin{array}{c}\text { Half-democratic } \\
\text { countries }\end{array}$ & 3 & 3 & 3 \\
\hline $\begin{array}{c}\text { Non-democratic } \\
\text { countries }\end{array}$ & 3 & 2 & 8 \\
\hline
\end{tabular}

Table 7. Democracy and Dominance in the Microstate Camp: Co-Variations During 73 Sub-Periods

\begin{tabular}{|c|c|c|}
\hline & Non-Dominance Periods & Dominance Periods \\
\hline \hline Democratic periods & 31 & 10 \\
\hline Non-democratic periods & 11 & 21 \\
\hline
\end{tabular}

Table 8. Electoral Methods and Dominance: Co-Variations During 41 Sub-Periods

\begin{tabular}{|c|c|c|}
\hline & Non-Dominance Periods & Dominance Periods \\
\hline \hline Plurality representation periods & 19 & 8 \\
\hline Proportional representation periods & 12 & 2 \\
\hline
\end{tabular}

dominance category in terms of size. In other words, whereas non-dominance has the upper hand, a lot of dominance still remains in the picture. Still, the listings in Tables $\mathbf{4}$ and $\mathbf{5}$ bring in a fairly clear verdict in the debate whether or not small units are as a rule tyrannized by majorities. The verdict is that the belief that small size promotes dominance appears ill-founded.

To understand better the pattern that has been described, two hypotheses will be examined. Reintroducing in the analysis the distinctions concerning democracy status that were presented earlier, the first hypothesis claims that dominance patterns are really about democracy, democratic contexts providing for non-dominance and non-democratic contexts providing for dominance. The relevant distributions are given in Tables 6 and 7. Table 6 provides a crossing of the dominance trisection that appeared in Table $\mathbf{5}$ and a corresponding trisection based on democracy status. This second trisection distinguishes between democratic countries, i.e. countries that have contributed democratic periods only to the analysis, half-democratic countries, i.e. contries that have contributed periods of democracy as well as periods of non-democracy, and non-democratic countries, i.e. countries that have contributed periods of nondemocracy only. The findings are straightforward enough. Democracy links to non-dominance in the great majority of cases, to half-dominance in a few cases, and never to dominance. On the other hand, non-democracy predominantly links to dominance. Given this rather clearcut pattern of co-variation, it is only logical and to be expected that the nine half-democracy cases are scattered evenly across the three dominance categories. Repeating this pattern, Table 7 lists periods rather than countries, the main finding again being that democracy contexts link to nondominance, whereas non-democracy contexts link to dominance. In all, therefore, the idea that dominance follows from a democracy shortage is substantiated. Admittedly, in cases with absolute regimes the idea is even self-evident, as non-democracy here equates dominance more or less by definition.

The second hypothesis to be examined is that dominance patterns are really electoral system consequences. The underlying idea is rather self-evident. It departs from the view that proportional representation brings about fragmented parliaments and coalition politics, hence patterns of non-dominance. Plurality representation, on the other hand, offers a bonus in seats to the party leading in votes, and thereby carries an ability to deliver government by a single majority party (Hague \& Harrop, 2004: 149). For obvious reasons, this hypothesis may be probed via an investigation of democratic regimes only, and this is done in Table 8, which is based on the 41 time periods that were classified in Table $\mathbf{1}$ as representing a democratic context. These periods are now cross-classified in terms of dominance and the electoral method that was in use in the country in question under the actual period. The classifications of periods in the categories of dominance and non-dominance follow from data given earlier in Table 4; the distribution is quite uneven, as there are 31 non-dominance periods as against only 10 dominance periods. The classification of electoral methods is likewise dichotomous, 
as it distinguishes between plural and proportional systems only. The distribution is again uneven, as there are 27 plurality representation periods as against 14 proportional representation periods. Data on electoral systems and electoral system changes are from a recent world-wide study on this very topic (Lundell, 2005: 249-254); the grouping that is applied here of various systems under the headings of plural and proportional systems are from the same source (Lundell, 2005: 11-34).

The distribution of cases on categories corroborates as well as speaks against the idea that dominance - nondominance fluctuation is a function of electoral method. When and if cases are selected on the dependent variable, the dominance category emanates from a pattern that is much in line with expectations. No less than eight dominance cases out of 10 confirm the view that dominance follows from plurality rule, and plural elections therefore come close to being in a probabilistic sense a necessary condition for dominance (Dion, 1998: 136-139). The two country exceptions to this rule are the dominance cases of Gyana and Malta, Guyana in fact promoting proportionalism to manage intense ethnic and ideological tension (Manley, 1999: 447448), and Malta being very specific, as this small island state combines the even extremely proportional single transferable vote system with the purest two-party system to be found under proportional representation anywhere in the world (Hirczy, 1995: 258). On the other hand, however, nondominance is not linked to proportionalism. No less than 19 out of a total of 31 non-dominance cases follow from plurality rule and it is, by the way, certainly worth noting that the impact of regime form on this distribution is negligible, the great majority of cases, dominance and nondominance alike, standing for parliamentary regimes. In sum, while the great majority of the dominance cases are in the realm of plurality representation, the great majority of plurality cases are in the realm of non-dominance. There are little signs here of a systematic election-dominance covariation.

One remark needs to be added. The sceptical reader may still wish to enter a caveat against the finding that small polities are not tyrannized by majorities. This caveat is about the possible existence of size thresholds even within the small states, the implication of this being, then, that the smallness-dominance link is operative for the smallest of the small but not for all small states. This suggestion is consistent with the view of Dahl and Tufte, who emphasized that their reasoning may apply to very small systems only, and who even voiced scepticism towards the investigation of the impact of size on an inter-country basis (Dahl \& Tufte, 1973: 94-95). Indeed, they maintained, the relevant threshold is most likely 'lower than the population of even a very small country like Iceland' (Dahl \& Tufte, 1973: 94). There is also some empirical evidence to support the belief that size thresholds mark the small state universe. An earlier investigation of the ten smallest island democracies in the world confirmed the thesis that there are no parties in such small systems, and if parties nevertheless exist, the party system will be predominant in nature (D. Anckar, 1997: 255256). However, when the same exercise was repeated for a set of 14 somewhat larger but still quite small island democracies, the theory was no longer confirmed (D. Anckar, 1997: 256). In other words, there was a difference between being small and being diminutive. A similar finding from recent research on the relation between size and democracy indicates that the smallest countries have a higher degree of democracy than larger states, this association between size and democracy, however, disappearing when the population size surpasses 500,000 (C. Anckar, 2008: 440).

In the materials now at hand, however, such a threshold effect is not visible. When diminutive countries that have populations of less than 100,000 are compared in terms of democracy periods with the remaining set of larger countries, the smaller countries contributing 19 periods and the somewhat larger countries contributing 24 periods, the outcome is that the dominance portion is almost exactly the same in both groups (five periods out of 19 in the first group; six periods out of 24 in the second). The size difference counts for nothing: it makes no difference if a unit is small or very small. This conclusion, however, may rest on shaky grounds. One is well advised to note that the very small units are precisely the same units which are in a lack of political parties and concerning which dominance conclusions therefore follow from other indicators that focus on individual office-holders. It may therefore be that the operationalization that has been used here accounts for the non-dominance aspect to a higher extent than the dominance aspect. Only detailed case studies can provide answers to the question to what extent this intervention really holds true; such case studies are unfortunately not at hand here and now. In conclusion: the finding that a threshold impact is lacking needs to be handled with some caution.

\section{CONCLUDING REMARKS}

The idea that small polities are tyrannized by majorities derives from observations and suggestions in the theoretical literature. Also, several long-time leaders of small nations immediately come to one's mind, who seemingly verify the notion of smallness being particularly subordinated to dominance - among such leaders are Forbes Sampson Burnham, Premier of pre-independence Gyana in 1964-1966, Prime Minister 1966-1980 and Executive President 19801985 (Sealy, 1991: 65-83; Lewis, 2001: 92-120); Vere Cornwall Bird, Prime Minister of Antigua and Barbuda 1981-1994 (Sealy, 1991: 35-47); Maumoon Abdul Gayoom, President of the Maldives from 1978 to 2008, and, indeed, Dame Mary Eugenia Charles, Prime Minister of Dominica 1980-1995 and the first female prime minister in the Caribbean.

Still, theory and anecdotes convey a biased impression. Of the 41 microstates that have formed the population of this study, 19 have not experienced dominance at all, whereas 11 have always experienced dominance and the remaining 11 have oscillated between dominance and non-dominance. Furthermore, of the 73 time periods during which the state performances have been observed, 42 are in a category of non-dominance. It is also evident from the data that a large portion indeed of the dominance pattern may be explained away by reference to democracy variation. Democratic countries display non-dominance in the great majority of cases and are seldom subjected to dominance; in contrast, non-democracy links predominantly to dominance. In other words, within the small polity universe, there is much 
variation in terms of dominance, and in this framework of variation, non-dominance clearly outweighs dominance. All small polities are not tyrannized; in fact, the characterization is valid for a minority of cases only.

How, then, contrary to the Madison expectation, have the small units been able to to ward off power petrifaction and immovable stability? Concerning the mechanisms that link small size and democracy Dahl and Tufte list several areas where small size can be expected to influence popular government (Dahl \& Tufte, 1973: 13-17; also C. Anckar, 2008: 435-436). Among these areas are: citizen participation (more effective participation), security and order (more voluntary compliance, less coercion), unity and diversity (homogeneity), common interest (easier to perceive a relation between self-interest and general interest), loyalties (more loyalty to a single integrated community), emotional life (civic relationship invested with high levels of affect, stronger pressures for conformity to collective norms), and rationality (greater speed and accuracy of communication, more opportunities for gaining knowledge, etc.). All these assertions are not unproblematic; the homogeneity assumption, to take one example, has been proved questionable and in need of qualification (D. Anckar, 1999). The point to be made here, however, is that most of these areas hold promises for citizen involvement, accountability and power-shifting. Rather than preserving and cementing faction constellations, they urge and support a controlled change of leadership.

This study ends on a comparative note. Against the finding that small polities are not majority-tyrannized, the objection may be raised that the study has been about small units only and that it may well be the case that these units, although predominantly representing non-dominance, are still more in the terrain of dominance than are large units. Small units, in other words, may have a relative propensity for dominance and may therefore still be more exposed to the tyranny of the majority. In consequence, the doctrine that represents the tyranny view is not necessarily altogether false. This intervention draws forth two refutations. First, there is little empirical reason to believe that larger units really are less exposed to a factional assumption of power; rather, the few relevant findings that are available are suggestive of negligible differences only between small and large. According to one relevant count, communist, unlimited presidential, military and absolute executive systems, which certainly all indicate dominance, are only slightly better represented in states with populations of less than one million than in larger states (Derbyshire \& Derbyshire, 1999: 47). A recasting of another relevant count indicates that of microstates with limited presidential executives, half of the heads of executives had in 1999 been in office for fewer than five years; the corresponding share of heads in larger states being slightly less than one half (Derbyshire \& Derbyshire, 1999: 52). Again, between small and large no perceptible difference is at hand. Second, be this as it may, the extent to which small polities are majoritytyrannized is, as evident from this study, small enough to warrant the assertion that governing smallness is really not about the uninterrupted and unchallenged rule by the same majority.

\section{REFERENCES}

Anckar, C. (2008). Size, islandness, and democracy: a global comparison. International Political Science Review, 29 (4), 433-459.

Anckar, D. (1997). Dominating smallness. big parties in lilliput systems. Party Politics, 3(2), 243-263.

Anckar, D. (1999). Homogeneity and smallness: dahl and tufte revisited. Scandinavian Political Studies, 22(1), 29-44.

Anckar, D. (2002). Why are small island states democracies? The Round Table, 365, 375-390.

Anckar, D. (2004). Regime choices in microstates: The cultural constraint. Journal of Commonwealth and Comparative Politics, 42(2), 206223.

Anckar, D. (2007). Demokratins kategorier och demonologi. Politiikka, 4 (1), 3-15

Anckar, D., \& Anckar, C. (2000). Democracies without parties. Comparative Political Studies, 33(2), 225-247.

Asher, A., \& Barnes, S. (1972). The dominant party system: a neglected model of democratic stability. Journal of Politics, 36(3), 592-614.

Dahl, R. A., \& Tufte, E. R. (1973). Size and Democracy. Stanford: Stanford University Press.

Derbyshire, J. D., \& Derbyshire, I. D. (1999). Political Systems of the World, (Vols. 1 and 2). Oxford: Helicon Publishing.

Diamond, L. (1996). Is the third wave over? Journal of Democracy, 7(3), 20-37.

Diamond, L., \& Tsalik, S. (1999). Size and democracy: the case for decentralization. In L. Diamond (Ed.), Developing Democracy: Toward Consolidation (pp. 117-160). Baltimore: John Hopkins University Press.

Dion, D. (1998). Evidence and Inference in the comparative case study. Comparative Politics, 30(2), 127-145.

Durotoye, Y. (1999). Republic of djibouti. In D. A. Kaple (Ed.), World Encyclopedia of Political Systems and Parties (Vol. I, pp. 301-302. $3^{\text {rd }}$ ed.). New York: Facts on File.

Elgie, R. (2008). The Perils of semi-presidentialism. Are they exaggerated? Democratization, 15(1), 49-66.

Fleischhacker, H. (1999). Sao tomé and príncipe. In D. Nohlen, M. Krennerich, B. Thibaut (Eds.), Elections in Africa. A Data Handbook (pp. 739-754). Oxford: Oxford University Press.

Foweraker J., \& Krznaric, R. (2000). Measuring liberal democratic performance: an empirical and conceptual critique. Political Studies, 48(4), 759-787.

Hadenius, A. (1992). Democracy and Development. Cambridge: Cambridge University Press.

Hague, R., \& Harrop, M. (2004). Comparative Government and Politics. An Introduction. (6th ed.) New York: Palgrave Macmillan.

Hamilton, A., Madison, J., Jay, J. (1961). The Federalist Papers. New York: New American Library.

Hirczy, W. (1995). Explaining near-universal turnout: the case of malta. European Journal of Political Research, 27(2), 255-272.

Hoefte, R., \& Oostindie, G. (1991). The netherlands and the dutch caribbean: dilemmas of decolonisation. In P. Sutton (Ed.), Europe and the Caribbean (pp. 71-98). London and Basingstoke: Macmillan Education.

Karvonen, L. (2008). Diktatur. Om Ofrihetens Politiska System. Stockholm: SNS Förlag.

Lewis, L. (2001). Linden Forbes Burnham (1923-85): Unravelling the Paradox of Post-Colonial Leadership in Guyana. In A. Allahar (Ed.), Caribbean Charisma (pp. 92-120). Kingston: Ian Randle Publishers.

Lijphart, A. (1992). Introduction. In A. Lijphart (Ed.), Parliamentary Versus Presidential Government (pp. 1-27). Oxford: Oxford University Press.

Linz, J. J. (1994). Presidential or parliamentary democracy: does it make a difference?, In J. J. Linz \& A. Valenzuela (Eds.), The Failure of Presidential Democracy (pp. 3-87). Baltimore and London: The Johns Hopkins University Press.

Lipset, S. M. (1996). What are parties for? Journal of Democracy, 7(1) 169 175.

Lundell, K. (2005). Contextual Determinants of Electoral System Choice. A Macro-Comparative Study 1945-2003. Åbo: Åbo Akademi University Press.

Manley, R. H. (1999). Cooperative republic of guyana. In D. A. Kaple (Ed.), World Encyclopedia of Political Systems and Parties, (Vol. II, pp. 447-450, $3^{\text {rd }}$ ed.). New York: Facts on File.

Ogashiwa, Y. (1991). Microstates and Nuclear Issues. Suva: Institute of Pacific Studies, University of the South Pacific. 
Ott, D. (2000). Small is Democratic: An Examination of State Size and Democratic Development. New York: Garland.

Sartori, G. (1976). Parties and Party Systems: A Framework for Analysis. Cambridge: Cambridge University Press.

Sartori, G. (1994). Comparative Constitutional Engineering. London: Macmillan Press.

Sealy, T. (1991). Sealy's Caribbean Leaders. Kingston: Kingston Publishers.

Somoza, A. (2001a). Federated states of micronesia. In D. Nohlen, F. Grotz, C. Hartmann (Eds.), Elections in Asia and the Pacific. A Data Handbook, (Vol. II, pp. 633-642). Oxford: Oxford University Press.

Somoza, A. (2001b). Kiribati. In D. Nohlen, F. Grotz, C. Hartmann (Eds.), Elections in Asia and the Pacific. A Data Handbook, (Vol. II, pp. 673-685). Oxford: Oxford University Press.
Somoza, A. (2001c). Tuvalu. In D. Nohlen, F. Grotz, C. Hartmann (Eds.), Elections in Asia and the Pacific. A Data Handbook, (Vol. II, pp. 823-832). Oxford: Oxford University Press.

Srebrnik, H. (2004). Small island nations and democratic values. World Development, 32(2), 329-341.

Thibaut, B. (1999). Seychelles. In D. Nohlen, M. Krennerich, B. Thibaut (Eds.), Elections in Africa. A Data Handbook (pp. 775-788). Oxford: Oxford University Press.

van Trease, H. (1993). The tabai years. In H. van Trease (Ed.), Atoll Politics. The Republic of Kiribati (pp. 48-73). Christchurch: Macmillan Brown Centre for Pacific Studies, University of Canterbury.

(C) Dag Anckar; Licensee Bentham Open.

This is an open access article licensed under the terms of the Creative Commons Attribution Non-Commercial License (http://creativecommons.org/licenses/by-nc/3.0/) which permits unrestricted, non-commercial use, distribution and reproduction in any medium, provided the work is properly cited. 